\title{
Laparoscopic Hysterectomy Assessment: A Multicenter Study in Dakar-Sénégal
}

\author{
Diallo M*, Fall KBM, Niang MM, Diouf AA, Daff HMB, Toure Y, Niass A, Koulimaya CEG and Mbaye M \\ Department of Obstetrics and Gynaecology, National Hospital of Pikine, Senegal
}

Submission: February 10, 2020; Published: February 24, 2020

*Corresponding author: Moussa Diallo, Department of Obstetrics and Gynaecology, National Hospital of Pikine, Senegal

\begin{abstract}
Summary
Objective: to define the epidemiological and clinical profile, specify the operative data and evaluate the prognosis aspects of patients who have undergone laparoscopic hysterectomy at the Dakar University Hospital.

Material and methods: This was a multicentric, prospective and descriptive study conducted over a period of 3 years (1 January 201531 December 2017), within three [1-3] renowned Gynaecology-Obstetrics Services in the Dakar region. The parameters studied, recorded on a collection form prepared for this purpose, were represented by: the socio-demographic characteristics of the patients (age, geographical origin, marital status, parity), medical and surgical history, clinical data, surgical indication data, complications, duration of hospitalization and outcomes. The statistical analysis was performed using IBM Statistical Package of Social Science version 20 software for Windows [4].

Result: During the study period, 61 hysterectomies were performed by laparoscopy out of a total of 383 cases of hysterectomies, representing a frequency of $15.9 \%$ [5-9]. The epidemiological profile of the patients was that of a woman aged on average 51 years. Ten [10] patients (17.9\%) had already had previous surgery. The indications were dominated by uterine myomatosis (35.1\%) and benign endometrial pathology (28.3\%). We had performed $68.9 \%$ total hysterectomy associated with bilateral adnexectomy. The average duration of the intervention was 132 minutes. The complications were represented by bleeding (6.6\%) and suppuration of colporraphy ( 2 cases). The average length of hospitalization was 3 days [11-20].
\end{abstract}

Conclusion: Laparoscopic hysterectomy is an intervention adapted to the management of utero-annexial benign lesions in our context. It is associated with low morbidity [21-30].

Keywords: Laparoscopic hysterectomy ; Indication ; Outcome ; Dakar

\section{Introduction}

Nowaday, hysterectomy remains the most common surgical procedure for uterine and adnexal benign lesions [10,31-36]. In the early 1990s, laparoscopy attempted to become established in the field of hysterectomy with the first coelioscopic vaginal hysterectomy, performed by Harry Reich in 1989 [37,38]. For several reasons, more or less justified, such as the extended operating time and a lack of trained surgeons in this technic, laparoscopy has been slow to take hold [7]. Thus, as things stand at present, 60 to $70 \%$ of hysterectomy are still performed by laparotomy, 30 to $40 \%$ by vaginal route and 3 to $5 \%$ by laparoscopy [30]. After three years of practice, we considered it necessary to evaluate the practice of laparoscopic hysterectomy at the three [3] renowned center in the Dakar region.
Patients and Methods

It was a prospective and descriptive study, running from January 2015 to December 2017, in 3 references centers in Dakar (National Hospital Center of Pikine, Philippe Maguilen Senghor Health Center and Military Hospital of Ouakam). All patients who received laparoscopic hysterectomy during the study period were included. They had all given their informed consent, and were all advised of the possibility of a conversion laparotomy. The main objective was to evaluate the practice of laparoscopic hysterectomy in order to determine their frequency, clinical aspects, to analyze indications, to evaluate surgical complications and to make recommendations to improve the quality of services $[39,40]$. 
We studied the socio-demographic characteristics of the patients (age, address, marital status, parity), medical and surgical history, clinical data, surgical indication, surgical intervention data, per-and post-operative complications, duration of intervention and hospitalization, and surgical outcomes. Computer data and statistical analysis were performed with IBM Statistical Package of Social Science (SPSS) version 20 software for Windows [41-45].

Result

During the study period, 61 laparoscopic hysterectomies were performed out of a total of 383 hysterectomy ( $15.9 \%$ of cases). The average age of the patients was 51 years (with borders between 36 and 69 years). The average parity was 4 with a majority of multiparous (62.3\% of cases), Table I. Only 17 patients $(27.9 \%)$ had previous surgery; the majority $(6.6 \%)$ had a myomectomy. The reasons for consultations were dominated by menstrual disorders such as menometrorrhagia (60.6\%) and chronic pelvic pain (21.3\%). Type 1 obesity was noted in four (4) patients (6.5\%). In our series, the most frequent surgical indication was uterine myomatosis (35.1\% of cases), followed by endometrial polyps and/or endometrial hypertrophies (28.3\%), and cervical dysplasia (6.7\%) $[46,47]$ (Table 1).

Table 1: Characteristics of patients who have had a laparoscopic hysterectomy at the University Hospital of Dakar.

\begin{tabular}{|c|c|c|c|c|}
\hline Patient Characteristics & \multicolumn{4}{|c|}{ Parameters } \\
\hline Age & \multicolumn{4}{|c|}{$51,15 \pm 8,25$ years } \\
\hline Weight & \multicolumn{4}{|c|}{$77,3 \pm 11,23 \mathrm{Kg}$} \\
\hline parity & $\begin{array}{c}\text { Nulliparous } \\
6(9,8 \%)\end{array}$ & $\begin{array}{c}\text { Primiparous } \\
4(6,6 \%)\end{array}$ & $\begin{array}{l}\text { Pauciparous } \\
13(21,3 \%)\end{array}$ & $\begin{array}{l}\text { Multiparous } \\
38(62,3 \%)\end{array}$ \\
\hline Type of hysterectomy (AAGL Classification) & \multicolumn{2}{|c|}{ Type II } & \multicolumn{2}{|c|}{ Type IV } \\
\hline
\end{tabular}

A uterine cannulation using a hysterometer moored to a Pozzi clamp was the most common (73\%). The pneumoperitoneum was performed using the Veress needle in $71 \%$ of cases (43 patients), open laparoscopy was performed in $29 \%$ of cases (18 patients). The trocar sites were preferably at the umbilical, the right and the left iliac fossa. As a surgical procedure, we performed a total hysterectomy with bilateral adnexectomy in $68.9 \%$ of cases $(42$ patients). The associated gestures were represented by a first adhesiolysis and a first myomectomy. Pelvic lymph node dissection and subvesical plication were also performed in the same patient whose surgical indication was stage $1 \mathrm{~b}$ squamous cell carcinoma of the cervix. A case of laparoconversion was observed after failure of the pneumoperitoneum installation. For all patients, a total hysterectomy was completely performed by laparoscopy. In our series, according to the classification of the American Association of Gynecological Endoscopy, laparoscopic hysterectomy were type IV in $9.8 \%$ of cases and type II in $90.2 \%$ of cases.

Colporraphy was performed, for the majority of our patients (90.2\%), by the vaginal route. A control of the hemostasis of the various uterine pedicles was carried out by laparoscopy for all patients. The average duration of the intervention was 132 minutes. In our series, four [4] intraoperative complications were observed. They were all related to a difficulty in hemostasis of the uterine pedicle $(6.6 \%$ of patients). The postoperative outcomes were simple in almost all patients (93\%). We had observed:

a) four (4) cases of anemia (6.5\%) of haemorrhagic origin related to difficulties in intraoperative haemostasis of the uterine pedicles. These patients all received a blood transfusion

b) two (2) cases of suppuration with dropping colporraphy $(3.2 \%$ in cases) whose treatment was antibiotic therapy and a resumption of colporraphy at day 8 post antibiotic therapy (Table 2).

Table 2: Distribution of patients by surgical indications (laparoscopic hysterectomy series at Dakar University Hospital between 2015 and $2017, \mathrm{~N}=61$ ).

\begin{tabular}{|c|c|c|}
\hline Operative Indication & Effective & Frequency (\%) \\
\hline $\begin{array}{c}\text { Uterine myomatosis/ endometriomas/ } \\
\text { adenomyosis/ dermoid ovarian cyst }\end{array}$ & 27 & 44,2 \\
\hline Endometrial pathology & 22 & 36 \\
\hline Cervical dysplasia & 3 & 4,1 \\
\hline Uterine prolapse & 3 & 4,1 \\
\hline Choriocarcinoma & 3 & 4,1 \\
\hline CPPs rebellious to treatment & 2 & 2,7 \\
\hline $\begin{array}{c}\text { Squamous cell carcinoma of the cervix } \\
\text { stage Ib1 }\end{array}$ & 1 & 1,3 \\
\hline TOTAL & 61 & 100,0 \\
\hline
\end{tabular}

\section{Discussion}

\section{Frequency}

Hysterectomy is the most common gynaecological intervention performed on women with an annual incidence of 60,000 cases in France, 100,000 in England and 600,000 in the United States $[11,33,42]$. There was an increase in the use of the laparoscopic route from 0.3 to $9.9 \%$ and a decrease in 
the use of the conventional laparotomy route from 73.6 to 63.0 $\%$. There has been no significant change in the frequency of the vaginal route (26.1\% on average), which remains an uncommon approach among Anglo-Saxons [47]. In our series, laparoscopic hysterectomy was performed in $15.9 \%$ of cases. It would be too early to attempt a comparison with the number of laparoscopic hysterectomies performed by Western teams where this activity is currently routine.

However, our squad is satisfactory compared to the African series [4]. Currently, a large part of hysterectomy can be performed by laparoscopy. This technique would benefit from being developed and popularized in our underdeveloped context, given the advantages of laparoscopy over laparotomy [18,34].

\section{Age}

The age criterion does not play a role in the choice of the laparoscopic approach. The age range varies according to the series from 42 to 60 years $[5,16]$. It can be practiced at any age. The average age of the patients in our series was 51 years, it is similar to that reported by several authors $[3,16,43]$.

\section{Surgical history}

In $27.8 \%$ of cases, patients had a history of pelvic surgery dominated by myomectomy. The history of cesarean section is not a contraindication to this route [40]. Assistance with laparoscopy remains important in the event of a history of surgery that can compensate for secondary adhesions making uterine extraction and uterine detachment difficult $[6,17,26,32]$.

\section{Indications for laparoscopic hysterectomy}

Most of the series reported in the literature show that the symptomatic fibromatous uterus is the main indication for laparoscopic hysterectomy. We also find cervical dysplasia and organic pathology of the ovary $[14,16,33,40]$.

\section{Realization of the pneumoperitoneum}

There was no accident at the realization of pneumoperitoneum in our series. On the other hand, in the literature, Jansen and al [24] report an accident rate of $0.24 \%$ for the installation of pneumoperitoneum. Hashizume and et al. [22], Chapron and et al. [8], Dubuisson and et al. [13] reported rates of $0.88 \%, 0.14 \%$ and $0.12 \%$ respectively.

\section{Surgical action performed}

In our series $68.9 \%$ of total hysterectomy with bilateral adnexectomy was performed. This rate is explained by the prevalence of menopausal patients in our series. The impact of adnexectomies after hysterectomy has not been rigorously investigated. Farquhar suggested that ovarian removal at the time of hysterectomy in women (mean age 40 years) was associated with a significant alteration in the frequency of sexual intercourse [15]. Garry confirmed both sexual activity and self-image were altered in patients whose ovaries were removed before age 45 [19]. After this age, there were no longer any obvious disadvantages to the quality of life and sexual activity associated with oophorectomy [20].

Only one laparoconversion was observed in our series consistent with the work of Sesti and et al. [41] who did not have any cases of conversion to laparotomy. In Richardson's study [40], however, laparoconversion was necessary in five (5) patients due to either massive bleeding or multiple adhesions. Mankinen [29] and Wattiez [45] estimate this risk of laparoconversion at 3\%.

Severe adhesions, uterine volume, excessive intraoperative bleeding, the occurrence of a digestive or bladder wound are often advanced to explain conversions $[1,25,44]$. Only one publication highlights a higher conversion risk for obese patients [27]. Studies on learning curves $[1,28,45]$ show that the operator's experience reduces this conversion risk. Knowledge of these risk factors had two major interests, namely informing patients and identifying technically difficult situations.

\section{Type of laparoscopic hysterectomy}

According to the classification of the American Association of Gynecological Endoscopy [35], in our series, laparoscopic hysterectomy was of type IV (9.8\%) and type II $(90.2 \%$ of cases). This rate is similar to Richardson's, which reports $93.9 \%$ laparoscopic hysterectomy compared to $6.1 \%$ pure laparoscopic hysterectomy [40].

In the authors' experience [3], complete laparoscopic hysterectomy is unlikely, as a combination of vaginal and laparoscopic approaches should be used to perform everything that is simple along each route, that is to say adnexal pedicles by laparoscopy, and treatment of uterine pedicles and opening of the vagina through the vaginal route.

\section{Duration of the intervention}

In our series, the average duration of the intervention was $132 \mathrm{~min}$. The operating time is clearly longer than that of vaginal hysterectomy, even for operators with significant experience: 75min for Härkki-Sirén [21] and 110min for Ikhena [23].

\section{Per and post-operative complications}

The results of this study show a success rate of $93.4 \%$. On the other hand, four (4) preoperative complications were observed of a haemorrhagic nature, that is to say a rate of $6.6 \%$; this rate is stackable [45] to that found by Fatima Zahra [16]. However, Amirikia [2] and Martin [32] found a haemorrhage rate of $2.6 \%$ and $4.1 \%$ respectively. The postoperative outcomes were 
simple for $93 \%$ of patients, joining the rates found by Davis [12] and Fatima Zahra [16]. Hysterectomy can be associated with major complications. More than a third of all procedures have at least one complication [45], but most of them are minor and inconsequential. However, in studies of sufficient size, between $2 \%$ and $5 \%$ of patients have severe bleeding and between 2 and 10 out of 1000 patients have ureteral lesions [32].

The overall mortality rate for hysterectomy in benign indications is about 0.4 per 1000 cases [31]. Wingo and et al. [46] in 1985 found higher abdominal mortality $(2.7 / 10,000$ for vaginal hysterectomies and 8.6/10,000 for abdominal hysterectomies). Rempen [39] did not observe any deaths for the vaginal route with laparoscopic assistance $(0 / 2275)$, which is also observed in our series.

\section{Length of hospitalization}

The average length of hospitalization for our patients was 3 days. The reduction in hospitalization time improves bed occupancy, reduces the cost of the procedure and reduces the risk of nosocomial infections [9], thereby relieving our hospital facilities and patients.

\section{Conclusion}

Laparoscopic hysterectomy is feasible and useful in our health and academic environment. Of course, it does not claim to replace either abdominal hysterectomy or vaginal hysterectomy. Its didactic interset in learning surgical technics and anatomy is relevant in our university hospital environment where sociocultural and financial constraints prevent us from obtaining sufficient logistics for practical work. This intervention requires a strong experience of surgeons through continuous training, animal model training and tutoring. A local maintenance team is essential to ensure maximum and permanent availability of the equipment.

\section{References}

1. OShea RT, Adelaide OP (1996) Laparoscopic hysterectomy Audit. J Am Assoc Gynecol Laparosc 3(4): 35-36.

2. Amirikia H, Evans TN (1979) Ten-year review of hysterectomies: trends, indications and risks. Am J Obstet Gynecol 134(4): 431-437.

3. Aubad Y, Pascal P, Grandjean MH, Baudet J (1996) Laparoscopically assisted vaginal hysterectomy for nonmalignant disease of the uterus. Report on a personal serie of 126 cases. Eur J Obstet Gynecol Reprod Biol 68(1-2): 147-154.

4. Belley PE, Mboudou E, Nana NT, Egbe OT, Doh AS, et al. (2009) L'hysterectomie totale Par voie coelioscopique: L'expérience de l'Hôpital Général de Douala, Cameroun. Clinics in Mother and Chil Health 6(2): 1135-1138.

5. Boike GM, Elfstrand EP, Delpriore G, Debra SRN, Steck HH, et al. (1993) Laparoscopically assisted vaginal hysterectomy in a university hospital: Repport of 82 cases and comparaison with abdominal and vaginal hysterectomy. Am J Obstet gynecol 168(6): 1690-1701.
6. Boukerrou M, Lambaudie E, Narducci F, Crepin G, Cosson M, et al. (2001) Hysterectomies pour lésions bénignes: que reste-t-il a la voie abdominale? J gynecol Obstet biol reprod 30(6): 584-589.

7. Chapron C, Laforest L, Ansquer Y, Fauconnier A, Fernandez B, et al. (1999) Hysterectomy techniques used for benign pathologies: results of a french multicenter study. Hum reprod 14(10): 2464-2470.

8. Chapron C, Pierre F, Harchaoui Y, Lacroix S, Beguin S, et al. (1999) Gastrointestinal injuries during gynaecological laparoscopy. Hum Reprod 14(2): 333-337.

9. Cissé ML, Gaye A, Patricia K, Gueye M, Thiam C, et al. (2013) Hystérectomie vaginale sur utérus non prolabé au centre de santé Roi Baudouin à Dakar au Sénégal: à propos de 110 cas. JSAGO 2: 15-19.

10. Cosson M, Querleu D, Crépin C (1994) Voies d'abord des hystérectomies pour lésions bénignes. Références en Gynécologie-Obstétrique 2: 230240.

11. Cosson M, Rabajally R, Querleu D, Crepin G (1998) Hysterectomy: indications, surgical routes, cases of adnexal or cervical conservation. Eur J Obstet Gynecol 80(1): 5-15.

12. Davis GD, Wolgamott G, Moon J (1993) Laparoscopically assisted vaginal hysterectomy as definitive therapy for stage III and IV endometriosis. J Reprod Med 38(8): 577-581.

13. Dubuisson JB, Chapron C, Decuypère F, Spirlet DM (1999) Classic laparoscopy entry in a university hospital: a series of 8324 cases. Gyneacol Endosc 8: 349-353.

14. El Ghaoui A, Parant O, Monrozies X, Reme JM, Tanguy Y, et al (1999) Hystérectomie vaginale pour fibrome. A propos de 453 cas. Comparaison rétrospective à 509 hystérectomies abdominales. Ann Chir 53(3): 201-205.

15. Farquhar CM, Steiner CA (2002) Hysterectomy rates in the United States 1990-1997. Am J Obstet Gynecol 99(2): 229-234.

16. Fatima Zahra SR (2011) Hystérectomie vaginale coelio-assistée. Université Cadi Ayyad, Morocco.

17. Fernandez H, Lelaidier C (1992) L'hystérectomie vaginale cœliopréparée. Lyon Chir 88:159-161.

18. Gadonneix P, Manhes H, Cavorzin LN (1993) Le bloc de cœlioscopie opératoire. Paris Vigot, p. 175.

19. Garry R (2005) The futur of hysterectomy. BJOG 112(2): 133-139.

20. Garry R, Fountain J, Mason S, Howe J, Napp V, et al. (2004) The evaluate study; two parallel randomized trials, one comparing laparoscopic with abdominal hysterectomy, the other comparing laparoscopic with vaginal hysterectomy. Br Med J 328(7432): 129-133.

21. Harkki-siren P, Sjoberg J, Tiitinen A (1998) Urinary tract injuries after hysterectomy. Obstet Gynecol 92(1): 113-118.

22. Hashizume M, Sugimachi K (1997) Neddle and trocar injury during lapa-roscopy in Japan. Surg Endosc 11(12): 1198-1201.

23. Ikhena SE, Oni M, Naftalin NJ, Konje JC (1999) The effect of the learning curve on the duration and peri-operative complications of laparoscopically assisted vaginal hysterectomy. Acta Obstet Gynecol Scand 78(7): 632-635.

24. Jansen FW, Kapiteyn K, Trimbos-Kemper T, Hermans J, Trim-bos JB, et al. (1997) Complications of laparoscopy: a prospective multicentre observational study. Br J Obstet Gynaecol 104(5): 595-600.

25. Jones RA (1993) Laparoscopic hysterectomy: a series of 100 cases. Med J Aust 159(7): 447-449.

26. Lambaudie E, Occelli B, Boukerrou M, Crepin G, Cosson M, et al. (2001) Hystérectomie vaginale et nulliparité: indications et limites. J Gynecol Obstet Biol Reprod 30(4): 325-330. 
27. Leonard F, Chopin N, Borghese B, Fotso A, Foulot H, et al. (2005) Tota laparoscopic hysterectomy: preoperative risk factors for conversion to laparotomy. J Minim Invasive Gynecol 12(4): 312-317.

28. Mabille de Poncheville L (1998) Cœliochirurgie gynécologique en France: Instantanée 1996. Résultats d'une enquête nationale. Thèse de Médecine.

29. Makinen J, Johannson J, Thomas E, Heinonen PK, Laatikeinen T, et al. (2001) Morbidity of 10110 hysterectomies by type of approach. Hum reprod 16(7): 1473-1478.

30. Maresh MJ, Metcalfe MA, McPherson K, Overton C, Hall V, et al. (2002) The Value national hysterectomy study: description of the patients and their surgery. BJOG 109(3): 302-312.

31. Martin X, Gjata A, Golfier F, Raudrant D (1999) Hysterectomie pour lesion benigne: peut-on tout faire par voie vaginale? J Gynecol Obstet Biol Reprod 28(2): 124-130.

32. Meka JL (2017) Hystérectomie vaginale pour lésions bénignes utéroannexielles: étude multicentrique, retrospective, et descriptive à propos de 620 cas colligés à Dakar entre le 1er Janvier et le 31 Aout 2015 [Mémoire]: UCAD, 2017, Senegal.

33. Menard A, Ravina JH, Fabre H (1999) Coelioscopie: aspects médicolégaux et prévention. Références en gynécologie obstétrique 6(1): 77 90.

34. Olive DL, Parker WH, Cooper JM, Levine RL (2000) The AAGL Classification System for Laparoscopic Hysterectomy. The journal of the American association of gynecologic Laparoscopists 7(1): 9-15.

35. Pokras R, Hufnagel VG (1988) Hystérectomies in the United States 1965-1984. Am J Public Health 78(7): 852-853.

36. Reich H (1992) Laparoscopic Hysterectomy. Surg Laparosc Endosc 2(1): 85-88.
37. Reich H, DeCaprio J, McGlynn F (1989) Laparoscopic Hysterectomy. J Gyneaocol Surg 5(2): 213-216.

38. Rempen A (1996) Laparoscopic assistance at vaginal hysterectomy: a litterature review. Arch Gynecol Obstet Gynecol 258(2): 57-64.

39. Richardson R, Bournas N, Magos A (1995) Is laparoscopic hysterectomy a waste of time? The Lancet 345(8941): 36-41.

40. Sesti F, Ruggeri V, Pietropolli A, Piccione E (2008) Laparoscopically assisted vaginal hysterectomy versus vaginal hysterectomy for enlarged uterus. JSLS 12(3): 246-251.

41. Sheth SS, Malpani AN (1995) Vaginal hysterectomy following previous cesarean section. Int J Gynaecol Obstét 50(2): 165-169.

42. Wang CJ, Yen CF, Lee CL, Tashu T (2004) Laparoscopically assisted vaginal hysterectomy for large uterus a comparative study. Europan Journal of Obtétrics and Gynecology and Reproductive Biology 115(2): 219-223.

43. Wattiez A, Cohen SB, Selvaggi L (2002) Laparoscopic hysterectomy. Curr Opin Obstet Gynecol 14(4): 417-422.

44. Wattiez A, Soriano D, Cohen SB, P Nervo, M Canis, et al. (2002) The learning curve of total laparoscopic analysis of 1647 cases. J Am Assoc Gynecol Laparosc 9(3): 339-345.

45. Wingo P, Huezo C, Rubin G, Ory H, Peterson H, et al. (1985) The mortality risk associated with hysterectomy. Am J Obstet Gynecol 152(7 pt 1): 803-808.

46. Yazbeck C, Dhainaut C, Batallan A, Letohic A, Madelenat P, et al. (2004) Le point sur l'hystérectomie cœlioscopique. La lettre du gyénécologue 296:15-18.

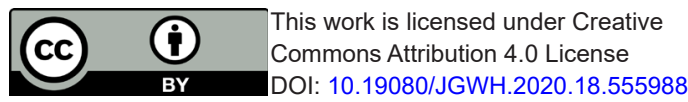

\section{Your next submission with Juniper Publishers will reach you the below assets}

- Quality Editorial service

- Swift Peer Review

- Reprints availability

- E-prints Service

- Manuscript Podcast for convenient understanding

- Global attainment for your research

- Manuscript accessibility in different formats

( Pdf, E-pub, Full Tsext, Audio)

- Unceasing customer service

Track the below URL for one-step submission https://juniperpublishers.com/online-submission.php 